\title{
INCORPORATING ROUTINE SCREENING FOR HISTORY OF CHILDHOOD SEXUAL ABUSE INTO WELL-WOMAN AND MATERNITY CARE
}

\author{
Julia S. Seng, RN, MA, and Barbara A. Petersen, CNM, EdD
}

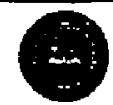

ABSTRACT

Despite a rapid expansion in the understanding of the incidence and effects of childhood sexual abuse in the mental health disciplines, health care disciplines have only begun to look at the effect of an abuse history on women's health. Little is known from research about its influence on a woman's gynecology care or childbearing experience. The literature across disciplines advocates for routine screening for history of childhood sexual abuse. Asking about childhood sexual abuse will benefit worien who have been abused and will help build a database from which to gain clinical knowledge aboul their care. This review presents clinical reasons to screen, discusses barriers and benefits, and emphasizes manageable ways to incorporate asting about childhood sexual abuse into practice.
\end{abstract}

Over the last decade, many articles and presentations have drawn our attention to the impact of childhood sexual abuse on women's health (118). Repeatedly, the literature in health care disciplines has advocated routine screening for past and current abuse $(1-3,5,12,14,18-20)$. The arguments for having health care providers screen for history of child. hood sexual abuse parallel arguments in the mental health literature also urging psychotherapists to screen their clients (21-25). Re. search and clinical experience, as will be discussed, show that the problem is widespread and that many of our clients' presenting problems or diff-

Address correspondence to Julia S. Seng. Nhrse-Midwitery Program. University of Mich. igan, 400 North ingalls. Reom 3320. Ann Ar. bot, Ml 48109 culties in the childbearing year may stem from prior abuse. Prognosis for improvement in physical and psychological well-being is poor if we do not know the cause of the problem. Still, many providers hesitate to ask women if they have ever been abused A review of the literature indicates how asking about a history of childhood sexual abuse is clinically important, examines barriers to asking, reassures us that it surely is better to ask than not to ask, and suggests manageable approaches to including such content in the visit.

\section{CLINICAL REASONS TO SCREEN}

Epidemiological studies suggest that between $15 \%$ and $38 \%$ of :Nomen in the general population have had un. wanted sexual contact belore 18 years of age $(1,26-28)$. Research on the sequelae of abuse shows a constellation of long-term effects that vary in prevalence and in severity. Mental health problems include depression, anxiety, low self-esteem, repeated tictimization, self-destructive behavior, substance abuse, sexual dysfunction, difficulties in intimate relationships, difficulties trusting, chronic tension, eating disorders, and symptoms of post-traumatic stress disorder (21-23, 29-31). Physical problems include chronic headaches, pelvic pain, dyspareunia, vaginismus, urogenital or gastrointestinal complaints, sleep disorders, and possibly severe premenstrual syndrome $(1,4,19,32,33)$. Abusive sexual contact that involves penetration can cause tissue damage and scarring. infection, and pregnancy, thus increasing gynecological risk factors.

Researchers and providers have 
only begen to explose the inpect of pest abuse on body trage, sel-core, and the woman's experience of pregnancy, bbor and birth, breast-

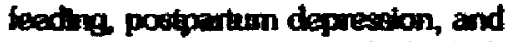
adtertion to mothemood $2,4-6$, 15-17, 34, 35).

Thene is aneodotal evidence and recent research to verify that a women with a thistory of childiood sexual abuse may experience physical exams and diagnostic or treatment procedures as intrusive and traumatic She may zuoid routine gynecological exams and needed care. She also may fear (or it may have been her experience in the past) that exams or procedures, birth, or breast-feeding will trigger flashbacks or body memories or that she will lose control and be embarrassed $(2$, $4,5,7-9,12,15,34,36\}$. The power dymamics and other aspects of her labor and birth experience may paraftel those of an abusive relationship $(10,16)$. For example, she may feel unable to object to the actions of a provider whose interpersonal style is authoritarian or "fatherly." Being told to "just relax" or "stop making so much noise" in childbirth may trigger memories of similar commands during an episode of abuse.

Julio S. Seng is a student in the University of Michigan Nuse-Miduifery

Program. She is a recipient of a 1994

American College of Nurse-Miduives

Foundation Scholarship and of the

Nurses' Educational Fund's Isabel

Mdssac Memorial Award. Survivors'

experiences with their health core and

childbearing are the focus of her

research interest

Barbaro A. Petersen ts on assistant professor of the Uniuerstry of Michigan School of Nursing where she is Coondinotor of the Nurse-Miduifery Program. She procices of the Hursel Hospital Nurse-Miduifery Service in Detrait, Michigan. She is a member of the American College of NurseMidurives and Sigma Theta Tau.
Being exposed or baing unveloone people present mey reenaca her va nerabity and inabitity to protect hesself The pain of bith thell or of hivang breat-foding may ted ure pain from abustue gearal conbact.

Without knouledge of a history of abuse, we may observe these problems but we us: overlook their cause, and we wit miss oppornmilies for appropriate treatment and healing If we know that the client has been abused, we can increase her comfont, control, and power by asting her how we can adapt our practice to meet her needs. This way, our care will not be traumatic to her or a reenactment of abuse and may, in fact. decrease her alienation from her body (7). (Holz [5] outlines ways to approach a well-woman visit with a survivor.) The long-term relationship formed for maternity care provides an opportunity to mutually develop a plan of care for the childbearing year. Such a plan needs to address special needs the pregnant woman may have for labor support and parenting support, and it needs to provide her with time to talk about her feelings all along the way. Finally, if we know that she has been abused, we should ask if she needs a psychological counseling referral to facilitate her recovery. During the emotionally charged childbearing year, she may especially benefit from the knowledgeable support of a therapist uho treats survivors $(1,4,15)$. This psychologist or social worker can also be a valuabte resource person for the nurse-mictwife.

\section{BARRIERS TO SCREENING}

Given the number of women with this history and the potential impact of abuse on their health, it is surprising that more women's health providers do not include questions about sexual abuse in their history taking. There are many possible explanations for why routine, unjversal screening has not been incorporated

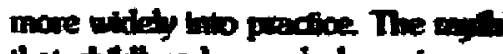

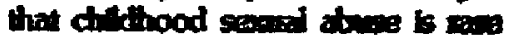
perists despite eudence to to cos. trany $(23,27,28,39,37-39$. May would argue thut not ority the at bet

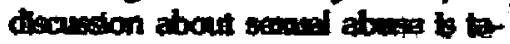

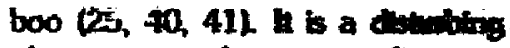
phenomenon that many chickens.

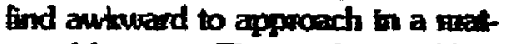
ter-offact way. The incidence of history of childhood sexual abuse among helping professionalsincluding nurses and physiciansmay be tigher than in the general population, which means that nearty half of us may be burdened with long-term effects of our own that we may fear bringing to the discusston (42). We may be concened that asting will provoke an emotional response that we are not prapared to manage. Nevertheless, there are many clinical reasons why we should ask about prior abuse. There are also abundant statements in the literature that should encourage and suppoit our efforts to incorporate this assessment into practice.

\section{SUPPORT FOR SCREENING}

The feminist psychiatrist Judith Herman (23) reassures us: "Asking about incest is like asking about any other taboo subject, such as akcoholism, violence, or suicide. If the [clinician] is reasonably comfortable posing the question, the patient will be comfortable answering it" Several studies that evaluated subjects' response to being questioned for research purposes assure us that the majority of survivors do not $\mathrm{mind}$ being asked $(19,39,41)$. Felitti's primary care screening study (19) revealed that more than $90 \%$ of the participants who had been abused had never been asked before. Only $3 \%$ of the abused partictpants responded angrity about being asked Of Russell's (39) 152 research subjects who had experienced incestuous abuse, 64\% were judged by the interviewers to be "very withg" to disclose their experiences, 33\% "w- 
ing." and only 3\% "unwilling." When asked how comfortable they felt answering the questions, $51 \%$ of the subjects answered "very comfortable," 27\% answered "somewhat comfortable," and 6\% "very uncomfortable."

A recent study by Robohm and Buttenthem (12) booked specticalliy at the issue of survivor disclosure to gynecology providers. Among the 44 survivor and 30 nonabused respondents who answered survey items about their experiences of disclosure, $84 \%$ said they had never been asked about a history of sexual abuse or assault by any gynecology care provider. When asked if they think that providers should ask, $93 \%$ of the survivors and $96 \%$ of the nonabused respondents said "yes" or "it depends," and $65 \%$ of the survivors gave an unqualiffed "yes."

It may boost our resolve to take the risk and ask if we realize that, far from harming the woman--and aside from any improvement in her experience of our care-merely asking the question may help her. Lister (25) addresses the traumagenic effect of the sectecy of childhood sexual abuse and states that giving permission to break the secrecy can be a powerful interverition and an aid to healing. As Herman stated in her classic book. Father-Daughter incest (23). "Direct questioning can be a great boon to patients who are troubled by their incest experience but who do not dare to raise the issue themselves. Over and over we have heard the testimony of victims who longed for the opportunity to talk about their experiences with a helping person and who waited in vain to be asked."

Many women who have been sexually abused are strong, have welldeveloped coping mechanisms, and may have benefited from some measure of healing (43). Others may suffer from a range of psychological sequelae, all the way from multiple per. sonality disorder to addiction to compulsive overachievement. Anticipating a Gynecological exam may not cause a survivor any more concern than it causes anyone else. On the other hand, it may cause her a range of feelings, from mild concem about bow the nurse-midwife will treat her, to worrying about how she will tolerate the exam, to anxiety bordering on a panic attack. When asked about sexual abuse, the survivor might answer that she has an abuse history but that it does not cause any major problems for her now. Ot the nurse-midwite might encountet a fragile woman already experiencing considerable anxiety who becomes upset.

Evoking a strong emotional response to the screening question might seem like the worst thing that could happen. But, it is not. It would be worse not to ask and to proceed with an exam that itself may cause a strong response.

With the history infornation, the nurse-midwife can provide emotional support and address the woman's particular concerns. If the exam is difficult for her, at least both people know what is going on. Problemsolving is focused on how to help rather than on trying to figure out what the problem is.

Without the history intormation, the emotional impact of the exam on the woman may be evident, but it will be more difficult for the nursemidwife to respond appropriately if she or he does not know the reason for the reaction. The emotional impact of the exam also may not be evident. It may happen more frequently than we know that the woman will suffer the feelings without any obvious affect. and the nurse-midwile will never be aware (12). At best, it will have been a missed opportunity for care, mutual satislaction, and healing. At worst, it will have been a trigger for anger. anxiety, and manifestations of posttraumatic stress and a retraumatization (7-9, 17, 36). Asking the ques- tion communicates therapeatic messages: She is not the only one We are open to knowing about her experience and its impact.

\section{APPROACHES TO ASKING}

In Robohm and Buttenheirn's study (12), it was found that those who had been abused wanted to be asked, but only if certain conditions wre met. They expressed concerns that the information be confidential, that they be asked while they were still fully clothed, and that the provider be "sensitive and knowledgeable about sexual abuse and its effects." Many of the survivor respondents who felt that the question should be asked reported that they felt unable to bring up the topic themselves. Others stated that they feared that providers who did not ask could not understand their experience or would not be prepared to hear about their experience.

Of course, the screening question may lead to more than a "yes" or "no" answer. We need to be willing to show acceptance and empathy as we bisten. The situation may indicate that further assessment would be appropriate. It is useful to see that in Courtois' initial 1980 study (41), in which sunvivors discussed the abuse in some detail, the women indicated that the brief opportunity to talk about their history was therapeutic.

We may have concems that the scheduling constraints for gynecology appointments do not allow for time to talk about this issue. Certainly, on any given day, we may not feel emotionally available to deal with this information empathetically. Even with these constraints, it is still possible to ask questions in a way that balances the needs of the client and the caregiver. One way to do this is to frame the question so that it limits the response to the context of the gynecology exam, for example. "Is there anything about your past expe- 
iences that nales this exan porticelaty dit art for you?" with a folbow uquector, What can I do to mate it easio for you?" Robohm JS, pexsonal communication). We may need to ofto to schedute an add: tonal appointiment in order to have enough the for someone who realy needs to thk about her concerns belore being examines. A more openended question can be reserved for circumstances in which we are tikely to have an on-going relationship with the woman and in which the impact of childhood sexual abuse will need to be explored in more depth, such as at an initial prenatal visit In this context, there is usually more time to devote to listening to how the woman thinks her history may affect her pregnancy and our care for her.

The screening question may also lead to a "no" answer from a woman who indeed was abused. She may be unaware of her history because she is among the survivors of abuse who repressed knowledge of the events in order to cope $(30,31,44,45)$. Even if she is aware of prior abuse, she may not trust yet or feel prepared to reveal such a personal matter at that moment, but she may bring it up again later ( 1,3 ). At least, she knows that her nurse-midwife is approachable and willing to listen.

Finally, we need not reinvent the wheel if this line of questioning is new to us. Several authors outline explicit but nonthreatening wording for screening questions $(5,43,46)$. "Were you ever sexually abused as a child?" is one simple way to ask. However, some women will not equate what happened to them with the societal labed "sexaual abuse" (let alone "incest"'. A question that focuses on her perception may be bet. ter. For example, "Did you have any unwanted sexual experiences when you were a child?" Each of us will need to try a lew different scripts for asking until we find one that is appropriale and comfortable. Although a witten question on an intake his- cay form midit seen les theaner ing foce-to-face ing'y by a sap. portive pesson seerus to ylid the greatest percentage of positure regponees $(14,26,39,47)$. Some woman have concems about having th's sentitue incomation in witing in their reconds. Others need to meet the provider and forr. some judgment of the provider's abitity to empathiee before cisclosing their history (12). Large services may want to expand their working knowledge through journal discussions or inservice programs and to include the subject in chart revieus as part of the peer-review process. Individually, we can also take advantage of networking relationships with therapists who treat survivors to ask for suggestions-or we can use the quest for suggestions as an impetus to network with therapists in order to develop our referral resources.

\section{THE IMPLICATIONS OF ASKING}

As we change our practice by actively seeling to leam if our clients have been abused, we may fear that this knowledge will cast a cloud over our work, that we will lose our positive orientation to the childbearing woman. In fact, it is likely that we have already encountered survivors in our practice and have been at least dimly aware of these women's trauma. By soeking to know for sire, we will gain the opportunity to provide more empowering. respectful, holistic, and clinically on-target care. We will have the privilege of helping the survivor take steps toward improving her physical and psychological health for the rest of her bife. In turn, her increased well-being can only improve the well-being of her family of creation. Last, but certainly not least, by breaking the taboo of silence about childhood sexual abuse. we are contributing to the work of stopping abuse from happening so that childhood will be safer, and wowen wis be giten the opportunity to be stronget and healisier.

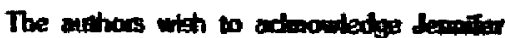

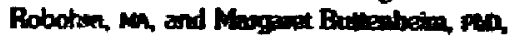
of the Criversty of Mintigen Depounant of

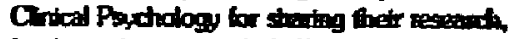
for thet atwocay on betell of the genesologe health care peedis of survicos, and for thelr encotragemera related to this review. We would the to express apprectation to Abse Brumer, PtD, and atoo to dane Hastnger. MEw, of the bnertiscoplinary Project to Fentust Practice at the Uhiversity of Michigan tor their contributions to the developrnent of tembinst practitioners.

\section{REFERENCES}

1. Bachman G, Moellex T. Bennett d. Childhood sexulal abuse and the consequences in adult women. Obstet Gynecol 1988;71:631-41.

2. Courtois $C$, Courtois-Riley $C$. Pregnancy and childbirth as trikgers for abuse memories: implications for care. Birth 1992;19:222-3.

3. Fumiss KK Screening for abure in the dinical setting. AWHONNs Clinical lssues in Prenatal and Women's Health Nursing 1993:4:402-5

4. Grant LJ. Effect of childhood sexual abuse: issues for obstetric caregivers. Birth 1992;19:220-1.

5. Hotz KA. A practlcal approach to clients who are survivors of childhood sexalal abuse. I Nurse Mitwitery 1994; 39:13-8

6. Jacobs JL. Child sexual abuse victimization and laler sequelae during pregnancy and childbirth. Joumal of Ched Sexual Abuse 1992;1:103-12.

7. Kitzinger J. Recalling the pain Nurs Times 1990,86:38-40.

8. Kitinger J. The intemal examination. Practutioner 1990,234:698-700.

9. Kitzinger J. Counteracting not reenacting the violation of women's bodies: the challenge for perinatal caregives. Birth 1992:19:219-20.

10. Kitzinger $\mathbf{S}$. Birth ano violence against women: generating hypotheses from women's accourts of unhapiness after chidbirth is: Roberts $\mathrm{H}$ (ed). Wo 
wen's heatth matters. London: Rousledge, 1992

11. Moore DS. A therature review on sexalal abuse I Nurse Miduitery 1994; 2439-8.

12 Robohm JS, Butsenheim $M$ The gnecological care experience of adult survivors of chilk thood sexuld abuse. The American Psychological Association Confenence on Pyychosocial and Behav rord Factors in Women's riealth: Creat. ing an Agenda for the 21st Cantury. Washington (DC), May 13, 1994.

13. Rase A Effects of childhood sexual abuse on childbirth: one woman's story. Birth 1992;19:214-8.

14. Sampselle C, Petersen BA, Murtland TC, Oakley DJ. Prevalence of abuse among pregnant women choosing certilied murse-midurves or physictan providers. d Nurse Miduifery 1992;37:425-8.

15. Simpkin P. Overcoming the les acy of childhood serual abuse: the role of caregivers and childbirth educators. Bith $1992 ; 19: 224-5$.

16. Stmplin P. The impact of child. hood sexual abuse on the birthing woman. Midwifery Today Conference. Eugene (OR), 1993.

17. Stevens L Working with adult sur vivors of childhood sexulal abuse. Amer. ican Colleye of Nurse-Midwives 38th Annual Meeting. Nashville (TN), 1994.

18. Urbancic J. Intrafamilial sexual abuse. In: Campbell J, Humphreys J (eds). Nursing care of survivors of family violence. St Louis (MO): Mosby, 1993.

19. Felitti VJ. Long-tem medical consequence of incest, rape, and molesta tion. South Med J 1991;84:328-31.

20. Hall LA, Sachs B, Rayens MK Lutenbacher M. Childhood physical and sexual abuse: their relationship with depressive symptoms in adulthood. Image Joumal of Nursing Scholarship 1993:25: 317-23.

21. Briere J, Runtz M. Post sexual abuse trauma: data ard implications for clinical practice. Joumal of Interpersonal Violence 1987:2:367-79.
22. Gelinas $D$. The persisting negatwe effects of incest Am J Psyctiatry 1983 46.312-32

23. Herman IL. Father-daughter incest Cambridge (MA): Harvard Universty Press, 1981.

24. Lanktree C. Briere J. Zatd L bncidence and impact of sexual abuse in a child inpatient sample: the role of direct inquiry. Child Abuse Negl 1991:15:44753.

25. Lister E. Forced silence: a neglected dimension of trauma. Am J Psychiatry $1982 ; 139: 872-6$.

26. Finkelhot D. A sourcebook on child sexual abuse. Beverly Hills (CA): Sage, 1986.

27. Russell DEH. The incidence and prevalence of intrafamilial and extrafarniljal abuse of temale children. Child Abuse Negl 1983;7:133-146.

28. Wyatt GE. The sexual abuse of Afro-American and white Ametican women in childhood. Child Abuse Negl 1985;9:507-19.

29. Finkelhor D. Early and long-tem effects of childhood sexual abuse: an update. Professional Psychologist: Research and Practice 1990;21:325-30.

30. Herman JL. Trauma and recovery: the aftermath of violence-hrom domestic abuse to political terror. New York: Basic Books, 1992

31. Herman JL. Russell DEH. Trochi K. Long-term effects of incestuous abuse in childhood. Am J Psychiatry 1986; 143 $1293-6$

32. Caldirola D, Gemperle M, Guzinsto $G$, Gross R, Doen $H$. Incest and pelvic pain: the social worker as part of a research team. Health Soc Work 1983;8: 309-19.

33. Loewenstein RJ Somatoform dis orders in victims of incest and child abuse. In: R. Kuft (ed). Incest-related syndrome of adult psychopathology. Washington (DC): Amencan Psychiatric Press, 1990.

34. Sperlick M. Miduifery care. Above a Whisper 1993;3(4):8-9.
35. Wextund E Women's seari'ty atter childhood incest. New York: Norton, 1992.

36. Bhurne ES. Secret survivors un covering incest and its aftereflects in women. New York: John Whey and Sons, 1990

37. Hemar dL Schatzoun E Recovery and verfification of memories of chitdhood senatad trauma. Pyychoanatylic Psy chology 1987:4:1-14.

38. Kuft $R$ (ed). Incest-related symdrome of adult psychopathology. Wash ington (DC): American Fsychiatric Press, 1990.

39. Russell DEH. The secret trawna: incest in the lives of girls and women. New York: Basic Books, 1986.

40. Armstrong L. Kiss daddy goodnight a speakout on incest New York: Hawthome. 1978.

41. Courtois $C$. Stuctying and counseling women with past incest experience. Victimology 1980;5:322-34.

42. Briere J. Child abuse trauma: theory and treatment of the lasting effects. Newbury Park (CA): Sage. 1992

43. Dinsmore C. From surviving to thriving: incest, feminism, and recovery. Albany (NY): State Unversity of New York Press, 1991.

44. Courtois $\mathrm{C}$. The memory retrieval process in incest survivor therapy. Journal of Child Sexual Abuse 1992.1(1):1532.

45. Tert L. Childhood traumas: an outline and overview. Am d Psychiatry 1991;148:10-20.

46. Meiselman KC. Resolving the trauma of incest San Francisco: JosseyBass, 1990.

47. Wyatt GE, Laurence J. Voudounon A, Mickey MR The Wyatt sex history questionnaire: a structured interview for female sexual history taking. Journal of Child Sexual Abuse 1992:1(4):51-68. 